\title{
Alienation between the Critique of Dialectical Reason and the Critique of Economic Reason Sketch of a Materialist Ethics
}

\author{
Chiara Collamati
}

\begin{abstract}
Through an analysis of the category of alienation in the Critique of Dialectical Reason, this article aims to shed light on the way in which Sartre attempts to think through alienation both with Marx and going beyond Marx. Sartre does not reduce alienation either to an ontological dimension of praxis or to the exclusively socio-economic determination of the capitalist mode of production. In order to grasp better the theoretical stakes of Sartre's position, André Gorz's analyses of the link between labour and alienation is discussed. The path via Gorz (who always insisted on his philosophical indebtedness to Sartre) is useful in order to ascertain whether it is justified to adopt the Sartrean dialectic of praxis and alienation as the basis of a critique of labour in the present configuration of the capitalist system. These questions will be taken as a starting point for an ethical and political examination of the category of need, as it is problematized by Sartre in the Critique and above all in the manuscript of "Les Racines de l'éthique" (1964).
\end{abstract}

Keywords: alienation, ethics, Gorz, labour, Marx, need, objectification, praxis

A quoi bon se demander si l'histoire est faite par les hommes ou par les choses, puisque de toute évidence les initiatives humaines n'annulent pas le poids des choses, et que la 'force des choses' opère toujours à travers les hommes? C'est justement cet échec de l'analyse, quand elle veut tout rabattre sur un seul plan, qui dévoile le vrai milieu de l'histoire.

[Why ask if history is made by men or by things, since it is obvious that human initiatives do not annul the weight of things, and the "force of 
things' always acts through men? It is just this failure of analysis, when it tries to bring everything down to one level, which reveals history's true milieu.]

Maurice Merleau-Ponty, Signes ${ }^{\mathrm{I}}$

The status of critique as practical experience of thought (i.e. as practice of philosophy, in both respects of the genitive) is at the heart of Sartre's writing in the 1960s and is very much crystallised in the production of the Critique of Dialectical Reason. ${ }^{2}$ The act of putting reason to the test of critique is aimed at allowing the evaluation (and possibly the foundation) of the heuristic value of Marxism as a living philosophy, as a thought that is capable of exerting a transformative influence and of having real purchase within a specific historical horizon.

The aim of the Sartrean variant of critique is thus emancipation, as it seeks to grasp the socio-historical foundations of alienation within a given society. To this end it is necessary to define more closely the usage and the origin of Marx's categories (and the different subsequent readings thereof), in order to identify the way in which they are both determined by and in possession of the power to determine history. Critique requires the avoidance of an attitude that considers the dialectic as a metaphysical law of thought, of history or of nature. On the contrary, through a process that is itself dialectical, the dialectic has to render intelligible the different modes of relations, interactions and reciprocal transformations that take place between human beings and their socio-historical milieu.

Moreover, between the projecting and the creative dimension of praxis and the ensemble of conditioning factors that continually act on praxis, thereby modifying its results to the point of turning them against it, historical activity is deprived of the possibility to know itself whilst making itself. While this last point might encourage a reading that attributes an unavoidable and co-substantial degree of alienation to the very notion of praxis, the present article will insist on the complexity of the notion of alienation in the Critique of Dialectical Reason.

To this end we shall consider the critical theory of labour developed from the mid-1970s onwards by André Gorz, for whom labour is and remains impossible for workers to appropriate, regardless of their degree of organisation, and regardless of the prevailing form of ownership or relations of production. Labour can only manifest itself as an external entity, as a power coming from the outside, always eluding all efforts to master or socialise it. Although Gorz continued 
to emphasise his philosophical indebtedness to Sartre, his analyses of the relationship between work and alienation seem to contain several problems, particularly if considered from a Sartrean perspective. Although necessarily too brief and incomplete, the reference to Gorz will serve here as an indication of the legitimacy of accepting the Sartrean dialectic of praxis and alienation as a basis for a critique of labour in its current configuration under the capitalist system.

Lastly, the third part of this article will examine the possibility of developing a fresh approach to the category of need, in so far as it represents the pre-condition for an act capable of transforming the real, or more precisely, as the root of a materialist and dialectical ethics.

\section{Alienation in the Critique of Dialectical Reason}

In the passages dedicated to collectives and to class-being, ${ }^{3}$ Sartre considers the problem of alienation not so much from the point of view of the past - where, as he says, recurrence and alienation constantly encounter one another - but rather from the point of view of the future. The question is therefore if the disappearance of capitalist forms of alienation would be identical with the suppression of all forms of alienation. Reiterating a series of questions formulated by Hyppolite in his Études sur Marx et Hegel, ${ }^{4}$ Sartre asks:

Dans quelle mesure une société socialiste bannira-t-elle l'atomisme sous toutes ses formes? Dans quelle mesure les objets collectifs, signes de notre aliénation, seront-ils dissous dans une véritable communauté intersubjective où les seules relations réelles seront celles des hommes entre eux, et dans quelle mesure la nécessité pour toute société humaine de rester totalité détotalisée maintiendra-t-elle la récurrence, les fuites et partant les unités-objets comme limites de l'unification vraie?

[To what extent will a socialist society do away with atomism in all its forms? To what extent will collective objects, the signs of our alienation, be dissolved into a true inter-subjective community in which the only real relations will be those between men, and to what extent will the necessity of every human society remaining a detotalised totality maintain recurrence, flights and therefore unity-objects as limits to true unification? $\left.{ }^{5}\right]$

If Sartre does not directly answer these questions, which he relegates to the space of a footnote, it is nonetheless possible to trace the coordinates of his position on the issue. His effort to think through the fundamental relationship that each human being entertains with the world and with others via the intermediary of worked matter, finds in the category of scarcity the element which, by transforming 
the Other into an enemy, allows Sartre to determine the specific type of intersubjectivity involved in the labour process. The latter is by no means a transparent, neutral, original and communitarian co-operation, which is afterwards subsumed by alienation and exploitation.

Instead, labour is a collective process that is always and already perforated by scarcity. The practico-inert stases that are incumbent upon it in the form of exigencies, are historically defined by a social regime that is grafted on a contingent situation characterised by scarcity - although human history can in no way disregard this kind of conditioning.

The cause of man's inhumanity - the effects of the alienation that characterises exploited forms of labour - is therefore historically permanent but also ontologically accidental. To put it differently: there is no necessity to history as it is; ${ }^{6}$ and it is precisely in such a space of non-necessity that transformative possibilities open up for and through praxis.

For Sartre, alienation as it is generated by the capitalist system of production is by no means the only form of alienation to which praxis is exposed. Praxis is constantly robbed of the meaning and the intention of its actions; it is continually forced to face unforeseen and contradictory results. On this the Critique is rather clear:

Pour que la société historique se produise elle-même comme lutte de classe, il est précisément nécessaire que la praxis détachée d'elle-même revienne aux hommes comme réalité indépendante et hostile. Non pas seulement dans le cadre du processus capitaliste, mais à tout moment du processus historique. ... C'est à l'intérieur de ce complexe de relations dialectiques que se constitue la possibilité du procès capitaliste comme un des moments historiques possibles de l'aliénation.

[For historical society to produce itself through class struggles, it is necessary for praxis, having become detached from itself, to return to men as an independent and hostile reality - not only in the context of the capitalist process, but also at every other moment of the historical process. ... It is within this complex of dialectical relations that the possibility of the capitalist process constitutes itself as one of the possible historical moments of alienation..$\left.^{7}\right]$

If this opens up a fundamental distance from Marx's conception according to which alienation stems from exploitation, Sartre further refuses to conceive of alienation as an entirely negative phase that men should strive to overcome once and for all by means of a definitive victory over scarcity. He eschews such a conception not only because the end of scarcity would, in some sense, entail the end of history ${ }^{8}$ but also (and above all) because the main challenge highlighted throughout the Critique consists precisely in the possibility 
of turning alienated and alienating situations into conditions from which a process of liberation can be begun - a liberation which, in the absence of any certainties or established terms, can profoundly modify the ways in which human beings think of themselves and act collectively. Sartre acknowledges Marx's contribution (in the Manuscripts of $1844^{9}$ ) of having distinguished (against Hegel) objectification from alienation, ${ }^{10}$ and of having valorised the former as a unique relationship between human beings and nature whilst situating the latter in its historical dimension, liable to be analysed in all its structural specifications. Simultaneously, Sartre highlights as one of the dangers of Marxism the desire to suppress, in a more or less distant future, the dialectical tension between alienation and objectification; a tension that is constitutive both of singular existence and of the movement of history altogether:

Chacun de nous passe sa vie à graver sur les choses son image maléfique qui le fascine et l'égare s'il veut se comprendre par elle, encore qu'il ne soit pas autre chose que le mouvement totalisant qui aboutit à cette objectivation.

[All of us spend our lives engraving our maleficent image on things, and it fascinates and bewilders us if we try to understand ourselves through it, although we are ourselves the totalising movement which results in this particular objectification. ${ }^{11}$ ]

We should recognise that the Critique remains ambivalent as to the distinction between alienation and objectification; ${ }^{12}$ nevertheless, we can retain that for Sartre the point is not to pursue an entirely dealienated condition in which praxis would be transparent to itself, capable of returning to a lost essence or even to a reassuring identity with itself and with its actions.

In order to describe and analyse the processes of capital, it is necessary to understand the (subjective) modes in which agents who are involved in these processes 'exist their own alienation', as they overcome their alienation through a transcending moment which is itself a renewed alienation. ${ }^{13}$ Sartrean alienation can thus neither be unequivocally reduced to an ontological condition of existence, nor to a phenomenon that pertains exclusively to capitalist relations of production. ${ }^{14}$ Instead, it requires to be conceived (and lived) at the very crossroads of ontology and history, in the repercussions and countereffects that freedom experiences when it is engaged in the transformation of matter. 


\section{Gorz or the Critique of Work as Critique of Alienation}

In his Métamorphoses du travail: Critique de la raison économique (1988), ${ }^{15}$ Gorz dedicates a chapter to the 'Condition of Post-Marxist Man', in which he criticises the idea, prevalent in numerous interpretations of the thought of the young Marx, according to which the full development of productive forces would go hand-in-hand with the full development of individual capacities, leading to a revolution that would take place both on the reflective-existential level and on the economic level. In this perspective, the breakdown of the productive system based on the exchange-value of labour would create the conditions for the free development of individuals, which constitutes the true goal of human activity, allowing osmotic exchange between human beings and nature. ${ }^{16}$ Liberation in work would thus constitute a necessary pre-condition for any perspective aiming at the liberation of work. $^{17}$

Contrary to this position which he attributes to the young Marx, Gorz believes that the liberation of work, just like the historical subject that is supposed to realise this liberation, cannot be the result of the simple development of the forces of production:

Le travail cesse, grâce à la rationalisation capitaliste, d'être activité privée et soumission aux nécessités naturelles; mais dans le moment où il est dépouillé de son caractère borné et servile pour devenir poïésis, affirmation de puissance universelle, il déshumanise ceux qui l'accomplissent.

[As a result of capitalist rationalisation, work ceases to be an individual activity and a submission to basic necessities; but at the precise point at which it is stripped of its limitations and servility to become poiesis, the affirmation of universal strength, it dehumanises those who perform it. ${ }^{18}$ ]

Capitalist rationalisation of production not only produces commodities; it also produces the figure of the individual who, 'aliéné dans son travail, le sera aussi, nécessairement, dans ses consommations, et, finalement, dans ses besoins' ['individuals who, being alienated in their work, will, necessarily, be alienated in their consumption as well and, eventually, in their needs'19]. In other words, Gorz refutes the idea that industrial labour is a form of objective progress in the sense of a moment that produces a generalised worker, the proletarian, who replaces private producers and thus forms a class for which work is immediately social, determined in its functioning by society as a whole, as the latter depends on seizing the social process of production in its entirety.

Setting out to deconstruct 'l'utopie du travail chez Marx' ['the utopia of Work in Marx's thought' ${ }^{20}$, (i.e. the thinking that brought 
the labour movement into contact with the idea of the dialectic of the forces of production and the relations of production; an idea that continues to feed into the ideology of work as the main terrain of political struggle), Gorz defends the notion of a fundamental complicity between labour and capital: for him, class struggle, immanent to the capitalist system, has in itself no potential to transcend this system - particularly since workers have an interest in maintaining the process of the self-valorisation of capital, not in abolishing it.

The Gorzian refusal of the logic of work necessarily implies a critique of the organisational strategy of the labour movement and aims at 'conquérir le pouvoir de ne plus fonctionner comme travailleur' ['winning the power no longer to function as a worker'21]. For him, the challenge is to explore the potential of a 'non-classe de non-travailleurs' ['a non-class of non-workers'] who, contrary to the working class, are not produced by capitalism and its relations of production but rather by the crisis of capitalism and by the dissolution of these relations due to the impact of new productive technologies. ${ }^{22}$

Gorz's reading forgets however that the category of class in Marx is not reducible to a static sociological concept: it exceeds the simple cartography of socio-economic stratification defined by labour. Instead, class for Marx is a dynamic category that acquires an anthropological and political dimension and that in each historical conjuncture acts as a rallying cry for political activism.

It is helpful to remember at this point Sartre's analyses of classbeing as a category that is constituted as divided between a subjective and an objective-structural dimension, between the actions of human beings and the circumstances in which they undertake these actions. ${ }^{23}$ In defining alienation as 'l'impossibilité de vouloir ce que l'on fait et de produire des actions que l'on puisse prendre pour fin dans leurs résultats comme dans les modalités de leur déroulement' ['the impossibility of willing what one does, or of producing acts that can be taken as ends both in their results and in the forms of their accomplishment' ${ }^{24}$, Gorz aims to propose 'un projet culturel, de société qui - comme fut le cas du projet socialiste - transforme en énergie politique l'exigence morale et le besoin de donner sens à l'avenir' ['a cultural project, a vision of the future, which - as the socialist project did - transforms moral demands and the need to give meaning to the future into political energy'25].

To this end, Gorz invokes 'l'autonomie du politique' ['the autonomy of the political'], which he considers to be a necessary condition of any transformative act and which implies in return 'l'autonomie de l'exigence éthique' ['autonomy of the ethical imperative'], that 
aims at 'le libre épanouissement des individualités dans la poursuite d'activités sans rationalité économique' ['the free self-realisation of individualities through activities which have no economic rationality']. As a consequence, the individuals who are the bearers of this exigency 'ne sont pas engendrés par la production socialement nécessaire ni par les activités périphériques nécessaires à la production matérielle' ['are not created by socially necessary production or the peripheral activities essential to material production'26]. They have to break with what Gorz calls 'la moralité objective' ['objective morality'], the main characteristic of which is that it exempts individuals from the task of interrogating themselves about the intended components of the modes and consequences of their actions. In other words, 'objective morality' dispenses individuals from the task of turning themselves into subjects, and in the name of unavoidable necessities instead allows them to turn themselves into and let themselves be turned into 'counter-men'.

Gorz's framework certainly has the merit of insisting on the historically determined character of the category of labour, as he warns against the risk of trans-historically attributing to social labour the characteristics that Marx analysed as being historically specific to labour under capitalism.

Nevertheless, his reading seems to suggest a recomposition of human activity and of praxis following the scheme of a 'téléologie de l'objectivation individuelle non aliénante' ['teleology of non-alienating individual objectification'], founded on the paradigm of objectivity as being constructed for the satisfaction of subjectivity. ${ }^{27}$ It would be politically illusory and philosophically dangerous to attempt an escape from the alienation of wage labour by appealing to the image of a free and de-objectified subject, hoping to oppose the 'autonomy' of such a subject to the hetero-determination of economic activities. Far from being able to constitute a horizon of liberation, the image of such a subject is, much rather, the precipitate and the result of alienation itself.

\section{At the Roots of Ethics: Objectification and Need}

This kind of objection to the critique of labour and to Gorz's reading of Marx has been formulated extensively in Franck Fischbach's Sans objet: capitalisme, subjectivity, aliénation. Our agreement with Fischbach is however only partial: he explains the weakness of the Gorzian conception of autonomy and moral exigency as the basis for 
Gorz's refusal of work. Fischbach attributes these ideas to a Sartrean heritage, which according to him continues to play a role in Gorz's framework, especially in the importance attributed by the latter to the 'subject' as subversive power. ${ }^{28}$ It seems, on the contrary, that in order to liberate Gorz's model from the risk of essentialist or naively subjectivist tendencies, it is necessary to return to the Sartrean definition of praxis as the 'passage de l'objectif à l'objectif par l'intériorisation' ['a passage from objective to objective through internalization ${ }^{29}$ ] and to take this approach further than Gorz does.

During the $1960 \mathrm{~s},{ }^{30}$ Sartre seeks to re-examine the theoretical framework provided by Marx in order to develop a theory of action that goes beyond mere will or (class) consciousness. His aim is to conceive historical action as a transformation of conditioning factors through the very elements that are shaped by this conditioning. Will and consciousness are in themselves insufficient instruments for such a transformation. At the same time, Sartre highlights the process by which the agent is transformed through the action that he or she him- or herself performs on conditioning factors. In the 1961 conference at the Gramsci Institute in Rome, Sartre spells the problem out in clear terms, asking to what extent subjectivity creates itself by creating objectivity. ${ }^{31}$

His answer is that subjectivity only exists in and through the action by which it turns itself into an object: continually turning itself into an object is the only way in which praxis can bring about a subjective transformation of objectivity. If in Search for a Method the subjective is already defined as 'moment nécessaire du processus objectif' ['a necessary moment in the objective process'), and praxis as 'passage de l'objectif à l'objectif par l'intériorisation' ('a passage from objective to objective through internalisation' ${ }^{32}$ ], Sartre in 1961 radicalises this conception by describing subjectivity as a shortlived transition between two moments of objective being:

Il n'y a donc qu'un moment qui s'appelle l'intériorité et qui est une sorte de médiation ... entre deux moments de l'être transcendent. ... Au fond, c'est le même être, qui procède à une médiation avec lui-même, qui est l'intériorité.

[So there is only one moment called interiority, which is a kind of mediation between two moments of transcendent being. ... Ultimately it is the same being, the same being in exteriority, which mediates with itself, and it is this that is interiority. ${ }^{33}$ ]

In the final part of the Rome lecture, Sartre uses the category of objectification in order to describe the relationship that subjectivity entertains with its own individual past and with its class affiliation. In 
both cases the possibility of distancing objective being as a conditioning determination and of opening up of a practical space for intervention emerges from the re-exteriorisation of objectivity through a singular way of acting. It follows that for Sartre, class is not a mere structure to then be filled with consciousness. Class struggle is therefore in his view an eminently political category that involves practices of collective action that have the potential to modify the material determinations of the social system which is guaranteed and implemented by economic and state power.

This capacity to 'de-condition' conditioning factors, to suspend facticity in the re-organisation of the practical field in view of arriving at a certain goal, this capacity is certainly linked to the projective structure of praxis in general. Sartre however also increasingly confers a strictly ethical significance to this aspect, since ethics '.. comme secteur particulier de l'activité humaine, ne serait même pas concevable si toute praxis ne se constituait pas d'abord comme éthos' ['as a particular region of human activity, would be unthinkable if praxis as a whole was not primarily constituted as $e^{t h} o s^{34}$ ].

The ethical dimension of historical praxis cannot be separated from its transformative and emancipatory power; this is why Sartre's endeavour to provide a phenomenological analysis of conduct in its ethical aspect ('conduites de moralité') necessarily requires a return 'au niveau de l'homme social au travail', 35 ['to the level of social man seen in the conditions of labour'] understood in relation to his position within the entirety of social relations of production.

This implies the recognition of the fact that the sphere of ethics in its essence bears the marks of material conditions, and that relations of production determine the very horizon of moral values. ${ }^{36}$ Sartre emphasises further the materialist character of ethics by situating the roots of the latter not within a principle of autonomy or reflexive will - which seems to be Gorz's approach - but rather in 'Man's very animality', in need and its demand for gratification. The satisfaction of need, which harks back to a primary challenge constituted by need itself, for Sartre opens up a dimension which can be neither passive nor alienating:

Le besoin n'est jamais une aliénation. Bien que son intensité et son objet puissent naître des circonstances historiques, il ne peut jamais être que la revendication vivante de l'homme nu. Mieux : il est la racine de l'autonomie, puisqu'il se pose lui-même et s'extériorise comme négation autonome d'un manque. ${ }^{37}$

[Need is never alienation. Although its intensity and its object can originate from historical conditions, it can never be anything but the living 
claim of naked Man. Moreover: it is the root of autonomy, since it establishes itself and externalises itself as autonomous negation of lack.]

It is significant that, in support of his position, Sartre has recourse to Marx's conception of need in order to demonstrate how it constitutes the emergences of 'the primary normative structure ('la première structure normative'):

Marx ... dit que le besoin se passe de toute justification. C'est en effet la seule détermination pratique, chez l'homme, qu'on n'ait pas à justifier par la médiation d'autres pratiques et d'autres fins. ... Par le cycle besointravail l'homme se constitue comme sa propre tâche. ${ }^{38}$

[Marx ... states that need is above all justification. It is in fact the only determination in human reality, that does not require justification mediated by other practices and other ends.... Through the cycle of need and work Man constitutes himself as his own task.]

The ethical significance of need, which Sartre evokes here, would require examination from two angles: one would firstly have to highlight the extent to which the heuristic-transcendental role that need occupies in the Critique ${ }^{39}$ is here being conceptually stretched. Secondly, the difficulties of the ethical component of need would have to be measured against their socio-historical context which is structured according to capitalist relations of production, in which the dialectic of production and reproduction of needs constitutes a fundamental element in the functioning of the system itself. ${ }^{40}$

Since there is not the space here to demonstrate the full implications of both these questions, we shall limit ourselves to a number of concluding remarks. First and foremost, it should be remembered that Sartre himself does not hesitate to recognise the extent to which individuals are denied the capacity to feel their own needs (and to claim the urgency of the satisfaction of those needs ${ }^{41}$ ). Sartre counts this circumstance among the effects of the exploitation of labour power, and Gorz follows him on this point. ${ }^{42}$ In certain historical and social conditions, need can itself be alienated and, rather than revealing a contradiction between a vital exigency and the impossibility of its satisfaction (a contradiction which would then function as detonator of revolt), need can become chronic and lead to a diminishing of vital forces and of the capacity for action, thus becoming itself an element of passivity. ${ }^{43}$

The possibility of a dichotomy between 'natural needs' and 'socially produced needs' is thereby rendered obsolete. There are no needs which could simply be qualified as 'natural', since this would imply the introduction of an essentialist conception of human nature, a 
naturalist vision of humanity which Sartre, following Marx, never ceased to criticise, instead insisting on the necessity of practising an all-encompassing historicisation of categories. ${ }^{44}$

Nonetheless, Sartre seems inclined to consider need not as an exclusively economic category but also as an anthropological dimension which can, in and of itself, acquire an ethical potential. This potential can certainly never present itself outside of history: embracing need as a normative structure of praxis means at the same time acknowledging that social life is determined by the relations of productions that assign a specific place within production to each individual. A materialist ethics rooted in need will thus be a praxis capable of intervening in the realm of the material production of these relations, and it will be driven by the urgency of those needs whose satisfaction can only be brought about through a transformation of relations between men.

Chiara Collamati obtained her doctorate in Political Philosophy and History of Political Thought from the University of Padova and the University of Toulouse II Jean Jaurès, having completed a thesis entitled "Dialectical Reason as Critical Experience: Praxis, History and Ethics in Jean-Paul Sartre's Philosophy (1956-1965)". She is a member of the "Gruppo di ricerca sui processi di soggettivazione politica nella società contemporanea" at the Université of Padova and she is a collaborator of the Groupe d'études sartriennes at the University of Liège. Her research interests include contemporary French thought, Marx's philosophy and a re-reading of Marxism from a hermeneutic standpoint influenced by Critical Theory and Conceptual History (Begriffsgeschichte).

Translated by Marieke Mueller and Kate KirkPatrick

\section{Notes}

1. Maurice Merleau-Ponty, Signes (Paris: Gallimard, 1960), 26; Signs, trans. by Richard C. McCleary (Evanston: Northwestern University Press, 1964), 20.

2. Translators' note: Thanks to Chiara Collamati for her help with translating this article from French. Where available, references to published translations have been provided. 
3. Cf. Jean-Paul Sartre, Critique de la Raison dialectique, précédé de Questions de méthode, Tome I: Théorie des ensembles pratiques (Paris: Gallimard, 1960), 286-377 (in the following referenced as CRD I). For the English translation see: Sartre, Critique of Dialectical Reason, vol. 1, trans. Aidan Sheridan (London: Verso, 1976), 228-342 (in the following referenced as CDR I).

4. Cf. Jean Hyppolite, Études sur Marx et Hegel (Paris: Libraire Marcel Rivière et Cie, 1955).

5. CRD I, 349, note; CDR I, 307-08 (note 92) (Sartre's emphasis).

6. See André Gorz's article 'Sartre et le marxisme' [1966] in Sartre, ed. Michel Contat (Paris: Bayard, 2005), 101-125: 'Sartre écarte toute conception métaphysique ou religieuse qui ferait de l'aliénation un statut du sujet dans son rapport à l'Être ou à la nature. L'aliénation n'est ni une fatalité naturelle (bien qu'il soit pratiquement impossible de la liquider en dehors de circonstances exceptionnelles), ni une caractéristique de la nature humaine (la notion d'aliénation serait dénuée de sens dans ce cas), mais un destin négatif qui vient à la praxis par la praxis des autres, sur la base de circonstances matérielles déterminées et par la médiation de la matière ouvrée. Montrer cela, c'est montrer du même coup que l'aliénation comme nécessité a un caractère historique et non pas ontologique ou métaphysique, et donc qu'elle doit en principe pouvoir être liquidée' (ibid., 115). [An (abbreviated) translation is available in André Gorz, 'Sartre and Marx', in Socialism and Revolution, trans. Norman Denny (London: Allen Lane, 1975), 237-270: 'Sartre rejects all religious and metaphysical definitions of alienation as pertaining to the subject in his relation to Being or to Nature. Alienation is neither a natural fatality nor an inherent characteristic of human nature; it is the negative destiny which praxis suffers through the praxis of others as mediated by worked matter, on the basis of determinate material circumstances (some of which, most notably scarcity, have a natural origin). The necessity of alienation, in other words, is something historical and not something ontological or metaphysical. In principle, it must therefore be possible to liquidate it' (ibid., 255-256).]

7. CRD I, 224; CDR, 151-52 (emphasis added). Translation modified.

8. '... malgré sa contingence la rareté est une relation humaine fondamentale (avec la Nature et avec les hommes). En ce sens, il faut dire que c'est elle qui fait de nous ces individus produisant cette Histoire et qui se définissent comme des hommes. Sans la rareté on peut parfaitement concevoir une praxis dialectique et même le travail ... Mais ce qui disparaitrait c'est notre caractère d'bommes, c'est-àdire, puisque ce caractère est historique, la singularité propre de notre Histoire', CRD, 201 (Sartre's emphasis).

['In spite of its contingency, scarcity is a very basic human relation, both to Nature and to men. In this sense, scarcity must be seen as that which makes us into these particular individuals producing this particular History and defining ourselves as men. It is perfectly possible to conceive of a dialectical praxis, or even of labour, without scarcity ... But what would disappear is our quality as men, and since this quality is historical, the actual specificity of our History would disappear too' CDR, 123-24 (Sartre's emphasis).]

9. Karl Marx, Manuscrits économico-philosophiques de 1844, trans. Franck Fischbach (Paris: Vrin, 2007).

10. The Critique is not unequivocal in its usage of these categories, as is revealed for instance by the rather ambivalent response that Sartre provides to his own question: 'Reviendrons-nous à Hegel qui fait de l'aliénation un caractère constant de 
l'objectivation quelle qu'elle soit ? Oui et non.' ['Should we go back to Hegel who sees alienation as a constant characteristic of all kinds of objectification? Yes and no.']. Sartre does however distinguish between objectification ('l'homme agissant sur la matière' ['Man acting on matter']), objectivity ('la matière totalisée agissant sur l'homme' ['totalised matter acting on man']) and alienation as 'destin en extériorité de la liberté' ['destiny in exteriority of freedom'] through which the agent recognises herself 'comme Autre dans sa propre objectivation singulière à partir d'un résultat autre' ['Other in one's own individual objectification on the basis of an other result'] (CRD I, 284-286; CDR I, 225-227 (Sartre's emphasis). We shall return to this question in the third part of this article.

11. CRD, 285; CDR, 227 (Sartre's emphasis).

12. In his article 'L'aliénation comme réification', Franck Fischbach analyses Sartre's conception of alienation (whose development he traces from L'Être et le néant to Saint Genet and the Critique). Published in Sartre et le marxisme, ed. Emmanuel Barot (Paris: La Dispute, 2011), 285-312. Fischbach paints a precise picture of the way in which Sartre problematises the relationship between alienation and objectification, and he chiefly relies on passages from the Critique in which these two terms can be identified. Fischbach then aims to produce a Marxist critique of Sartre's conception of alienation, which he brings into conversation with the Hegelian dialectic of Entäußerung and Entfremdung. We agree with Fischbach when he insists on the necessity to return to Marx's positive definition of objectification without turning the subject into a substantial entity with sovereign control over the objective world. However, it is our conviction that this idea in Marx is not to be reaffirmed against Sartre, but with Sartre, by following his notion of praxis as the movement between two moments of objective being, as a reciprocal modification between praxis and matter. On this point see also: Emmanuel Barot, 'Ecrire avec science comment l'Autre existe son aliénation. Sartre et les concepts fondamentaux de la sociologie', in Etudes sartriennes, no. 10 (2005), 55-75.

13. Jean-Paul Sartre, Questions de méthode (Paris: Gallimard, 1986), 163 (in the following referenced as $Q M$ ). For an English translation see Search for a Method, trans. Hazel Barnes (New York: Knopf, 1963 Hazel Barnes), 180.

14. On this ambivalence see Laurent Husson, 'Sartre et Lefebvre: aliénation et quotidienneté' in Sartre et le marxisme, 217-239.

15. Cf. André Gorz, Métamorphoses du travail: Critique de la raison économique (Paris: Gallimard, [1988] 2004), especially 46-121 and 149-273. Published in English as Critique of Economic Reason, trans. Gillian Handyside and Chris Turner (London: Verso, 1989).

16. Cf. Marx, Manuscrits de 1844.

17. It should nevertheless be clarified that Marx's position in this regard is neither simple nor unequivocal. It should suffice to mention that, in the Critique of the Gotha Programme, Marx vehemently refuses the view according to which labour per se constitutes an emancipatory force working towards a society that is fairer simply in the sense that wealth is distributed differently whilst leaving the distribution of the means of production unchanged. Gorz's position in this respect resonates with the views developed by Moishe Postone and the German-language journal Krisis (led by theoreticians such as R. Kurz, A. Jappe and N. Trenkle). See Moishe Postone, Time, Labour and Social Domination (Cambridge: Cambridge University Press, 1993), and the pamphlet 'Manifest gegen die Arbeit', Krisis, 1999, accessible online at http://www.krisis.org/.

18. Cf. Gorz, Métamorphoses du travail, 41-44; Critique of Economic Reason, 20. 
19. Ibid.; Critique of Economic Reason, 22.

20. Ibid., 49; Critique of Economic Reason, 23ff.

21. André Gorz, Adieux au Prolétariat: Au-delà du socialisme (Paris: Galilée, 1980), 93. English translation: Farewell the Working Class, trans. Michael Sonenscher (London: Pluto, 1982), 67.

22. 'La condition de l'homme postmarxiste c'est que le sens que Marx lisait dans le développement historique demeure pour nous le seul sens que le développement puisse avoir, mais que nous avons à poursuivre ce sens indépendamment de l'existence d'une classe sociale capable de la réaliser', Gorz, Métamorphoses du travail, 158 ['The condition of post-Marxist Man is that the meaning Marx read in historical development remains for us the only meaning that development can have, yet we must pursue this meaning independently of the existence of a social class capable of realizing it' (Critique of Economic Reason, 96)].

23. On this point see Juliette Simont, 'Sartre et l'être-de-classe', in Sartre et le marxisme, 25-44.

24. Gorz, Adieux au prolétariat, 132; Farewell, 93.

25. Gorz, Métamorphoses du travail, 161; Critique of Economic Reason, 98 (emphasis removed).

26. Cf. ibid., 162; Critique of Economic Reason, 98.

27. Cf. Jean-Marie Vincent, Critique du travail: Le faire et l'agir (Paris: PUF, 1987), 26-27.

28. Franck Fischbach, Sans Objet: Capitalisme, subjectivité, aliénation (Paris: Vrin, [2009] 2012), 260, note.

29. QM, 90; Search, 97.

30. In addition to the Critique, we shall in the following refer to the two lectures at the Gramsci Institute in Rome, given in 1961 and 1964 respectively. The former was published as Qu'est-ce que la subjectivité?, ed. Michel Kail and Raoul Kirchmayr (Paris: Les prairies ordinaires, 2013), in the following referenced as QQS. The 1964 lecture exists as a Manuscript at the BNF (Achat 85-22), and will soon be published by Jean Bourgault and Grégory Cormann, as 'Les Racines de l'éthique', in Etudes sartriennes, no. 19 (2015), in the following referenced as M64. To this should be added Sartre's preliminary manuscript for the Cornell Lecture [1965] published as 'Morale et Histoire', in Les Temps Modernes, no. 632-634 (2005), 268-414, in the following referenced as $\mathrm{MH}$.

31. Cf. $Q Q S, 97$.

32. Cf. QM, 90-91; Search, trans. Hazel Barnes (New York: Knopf, 1963), 97.

33. $Q Q S$ 38; for an abridged English translation see 'Marxism and Subjectivity', trans. Trista Selous, New Left Review 88 (July-August 2014), 88-111 (94). The objectified character of subjectivity is here another way of designating its necessarily incarnated state: 'Ce qui était pure inertie, gisement de négation, est devenu, par la conduite, une incarnation ... La singularité ou singularisation vient précisément de là' (QQS, 54-55) ['What was pure inertia, deposit of negation, has become, through behaviour, an incarnation ... This is precisely the origin of singularity or singularisation' (our translation)].

34. $\mathrm{MH}, 382$.

35. M64, 7 .

36. On this question see the extensive (and fundamental) footnote on ethics in the Critique: CRD I, 301-303; CDR 247-249, note 75.

37. M64, 35 .

38. Ibid., 31 (emphasis added). 
39. On this point see in particular Pierre Verstraeten's analyses in L'Anti-Aron (Paris: Éditions de la Différence, 2008). See also his 'Sartre/Foucault', in Etudes sartriennes, no. 5 (1991), 179-216.

40. As Fischbach emphasises: 'One of the most insidious effects of capital is that it deprives us of our needs, that it takes away our very capacity to feel our needs as such ... Capital has to deprive us of our original or natural needs because, when these are satisfied once and for all, capital would no longer have any perspective of valorization or growth: its valorization and expansion depend on the constant production of both artificial needs and of the mechanisms by which we feel these artificial needs as if they came from ourselves and as if they were natural. ... It is vital for capital that our needs grow with it, i.e. in an indefinite manner' (Sans Objet, 258-259).

41. For instance when he describes the situation of day labourers in the South of Italy, cf. CRD I, 178; CDR I, 95.

42. Gorz also insists on this aspect repeatedly, by highlighting how 'our needs are no longer natural ones, experienced spontaneously; they are needs produced in accordance with the needs of the profitability of capital' (André Gorz, Ecologica (Paris: Galilée, 2008), 62).

43. In an appendix added to the Cornell manuscript Sartre underlines the historical, social and cultural determination of need: 'In a constituted society ... reproduction as natural absolute is conditioned, penetrated by culture. ... Need is an internalised cultural fact as much as society chooses its undernourished members on the basis of scarcity. And since it chooses them on an ideologico-ethical level, malnourishment confers a certain cultural structure of need upon the practical agent' (MH, 40, emphasis added).

44. In Book I of Capital, trans. M. Rubel (Paris: Gallimard, 2008), Marx shows how the determination of the value of labour power, in contrast to other commodities, contains a historical and a moral element. The value of labour power is determined by the value of the means of subsistence that are habitually (i.e. following the habitus) necessary for the average worker. On this aspect of Marx's thought, one should consult Agnes Heller's much debated and criticised La théorie des besoins chez Marx (Paris: Union générale d'éditions, 1978). 